\title{
Wooden Drum Festival Suku Wa Di Ximeng Provinsi Yunnan
}

\author{
Riyana Istiqoma ${ }^{1}$, Anita Amran ${ }^{1}$, Tri Budianingsih" ${ }^{1}$ \\ ${ }^{1}$ Prodi Bahasa dan Kebudayaan Tiongkok, Fakultas Ilmu Pengetahuan Budaya, Universitas Al Azhar Indonesia, \\ Kompleks Masjid Agung Al Azhar Indonesia, Jalan Sisingamangaraja, Kebayoran Baru, DKI Jakarta 12110 \\ Penulis untuk Korespondensi/E-mail: tri.budianingsih@uai.ac.id
}

\begin{abstract}
Abstrak - Wooden Drum Festival adalah festival yang dirayakan oleh suku Wa di Yunnan, China. Festival ini dirayakan setiap tahunnya pada bulan November akhir atau Desember awal. Di antaranya ada tiga kegiatan utama yaitu Membuat dan Menarik Drum Kayu, Tarian Drum Kayu dan Sembahyang kepada Drum Kayu, serta terdapat pula kegiatan hiburan seperti perlombaan olahraga, pertunjukkan opera atau karnaval. Drum kayu adalah alat musik utama yang digunakan pada perayaan Wooden Drum Festival. Biasanya terbuat dari kayu merah dengan diameter 0,8 meter dan panjang sekitar 2 meter. Festival biasanya berlangsung selama tiga hari. Hingga saat ini festival ini masih terus dirayakan oleh suku Wa, karena mereka adalah suku yang sangat mematuhi ajaran agama.

Abstract - Wooden Drum Festival is a festival celebrated by the Wa tribe in Yunnan, China. The festival is celebrated annually in late November or early December. Among them are three main activities, namely Making and Pulling Wooden Drums, Wooden Drum Dance and Worshiping Wooden Drums, and there are also entertainment activities such as sports competitions, opera shows or carnivals. Wooden drums are the main musical instruments used in the Wooden Drum Festival celebration. Usually made of red wood with a diameter of 0.8 meters and a length of about 2 meters. The festival usually lasts three days. Until now, the festival is still celebrated by the Wa tribe, because they are a tribe that strongly adheres to religious teachings.
\end{abstract}

Keyword - China, Wa Autonomous Region, Wa Tribe, Wooden Drum Festival

\section{PENDAHULUAN}

\section{Latar Belakang}

China (Zhongguo 中国) merupakan salah satu

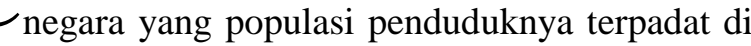
dunia yaitu 1,3 milyar jiwa, memiliki 56 suku dengan budayanya masing-masing. Suku-suku tersebut antara lain suku Hui (Hui zu 回族), suku Miao (苗族), suku Zhuang (壮族), suku Lisu (傈僳 族), suku Shui (水族), dan suku Wa (低族). $92 \%$ suku mayoritas penduduk China yaitu suku Han (Hanzu 汉族) dan 8\% lainnya merupakan suku minoritas (Shaoshu Minzu 少数民族).

Suku minoritas di China sebagian besar tersebar di daerah barat laut, barat daya dan timur laut China. Seiring berjalannya waktu sebagian besar suku minoritas telah pindah dan menetap di kota-kota besar di China dengan tujuan menuntut ilmu dan mencari pekerjaan di Yunnan (云南省) merupakan salah satu provinsi di China, terletak di bagian barat laut China yang banyak dihuni oleh suku minoritas diantaranya suku Bai (Bai zu 白族), suku Hani (Hani zu 哈尼族), suku Dai (Dai zu 傣族), dan suku Wa (Wa zu 恆族).

Kabupaten Ximeng (西盟县) merupakan salah satu kabupaten di provinsi Yunnan yang terletak antara kabupaten Lancang（Lan Cang 澜沧） dan sungai $\mathrm{Nu}$ (Nujiang 怒江), terhalang oleh gunung sekitar 2.000 meter di atas permukaan laut. Daerah ini disebut daerah berbukit Ava. Kabupaten Ximeng dengan iklim subtropis memiliki banyak curah hujan menjadikan daerah ini subur, cocok untuk menanam padi, jagung, gandum serta buah sub tropis seperti pisang, nanas, mangga, pepaya, dan jeruk. Kabupaten Ximeng memiliki populasi penduduk sebanyak 9,13 juta jiwa, dan 6,29 juta jiwa adalah suku Wa, selain itu juga ada suku Zhuang, suku Bai, suku Yao, dan suku Hui. 
Suku Wa merupakan suku minoritas yang unik karena sangat mengagungkan benda-benda yang terbuat dari kayu. Setiap benda yang berharga mereka buat dari bahan dasar kayu, salah satunya adalah alat musik drum. Hampir di setiap rumah warga suku Wa terdapat drum kayu yang dianggap dapat berfungsi sebagai pelindung, karena mereka menganggap drum kayu dapat melindungi pemilik rumah dari hal-hal yang buruk. Selain itu, suku Wa juga memiliki tarian tradisional yaitu Hair Swinging Dance (Shuai $\mathrm{Fa} W u$ 甩发舞) yang dilakukan dengan mengibas-ibaskan rambut mereka yang panjang. Setiap kibasan memiliki makna tertentu, misalnya apabila rambut dikibaskan ke depan berarti menyatakan selamat datang dan apabila rambut dikibaskan berulang kali menyatakan agar penonton dapat menikmati pertunjukan dengan gembira. Tarian ini dilakukan oleh beberapa gadis suku Wa pada saat perayaan Wooden Drum Festival ( Mu gujie 木鼓节.

Suku Wa terkenal akan budaya yang dimilikinya secara turun temurun, yaitu festival beras (Xin Mijie 新米节), Wooden Drum Festival, serta festival Imlek (Chun Jie 春节). Festival pada umumnya dimeriahkan dengan lantunan musik serta perlombaan-perlombaan untuk meramaikan acara. Wooden Drum Festival merupakan festival terpenting yang dirayakan oleh suku Wa pada bulan November atau Desember setiap tahunnya.

Pada tahun 1885, Inggris mulai memasuki provinsi Yunnan khususnya daerah Ximeng yang banyak dihuni oleh suku Wa dengan tujuan menyebarkan agama Kristen. Penyebaran agama ini berlangsung lama hingga pada tahun 1912, demi kelancaran misi Inggris menyebarkan agama Kristen, maka pihak Inggris mulai mengenalkan bahasa tulis kepada rakyat suku Wa. Setelah China memasuki masa pembebasan, pemerintah China membentuk sebuah lembaga penelitian khusus bahasa suku minoritas di China yang salah satunya adalah meneliti tentang bahasa Wa (bahasa tulis dan lisan). Setelah mengalami beberapa perubahaan, akhirnya pada tahun 1958 pemerintah China resmi memutuskan bahasa tertulis Wa sebagai salah satu bahasa resmi suku Wa yang terdiri dari 26 Abjad.

Sebagian besar warga suku Wa tinggal dipuncak atau lereng bukit. Membangun rumah di lereng bukit telah menjadi tradisi selama ratusan tahun. Pada awalnya terdapat sekitar 70 bangunan rumah suku Wa, dan hingga saat ini jumlah rumah mencapai 300 hingga 400 bangunan. Rumah kepala suku disebut "Rumah besar" ditandai dengan ukiran kayu khusus di atas pintu bagian depan, dinding dihiasi dengan tengkorak kerbau beserta tanduknya yang digantungkan yang berarti kekuatan dan kekayaan akan selalu dirasakan oleh pemilik rumah. Sedangkan penduduk biasa tinggal di rumah panggung yang ruang bawahnya digunakan sebagai kandang ternak.

Wooden Drum Festival tidak saja merupakan perayaan utama terpenting bagi suku Wa, juga merupakan waktu yang tepat untuk mengungkapkan perasaan pria terhadap wanita. Perayaan ini terkenal tidak hanya di provinsi Yunnan, tetapi juga di seluruh penjuru China. Pada saat perayaan Wooden Drum Festival banyak pengunjung dari berbagai daerah di China bahkan turis mancanegara datang untuk menyaksikkan perayaan festival ini.

Tujuan dari penulisan artikel ini untuk memaparkan pelaksanaan dan memberikan pengetahuan tentang Wooden Drum Festival suku Wa di kabupaten Ximeng, Provinsi Yunnan China. Metodologi dalam penelitian ini adalah kualitatif dengan studi pustaka dari sumber-sumber yang terkait dari berbagai buku, jurnal, baik dari sumber berbahasa China, Inggris maupun berbahasa Indonesia.

\section{Suku Wa Di Ximeng Provinsi Yunnan Geografi dan Populasi suku Wa di Ximeng}

Di China terdapat 117 daerah Autonomous County, salah satunya adalah Ximeng yang merupakan salah satu kabupaten di barat daya provinsi Yunnan dengan ibukota Pu'er (普洱) terletak di antara $22^{\circ}$ $45^{\prime} \mathrm{N}$ dan $99^{\circ} 29^{\prime} \mathrm{E}$ yang diresmikan oleh Pemerintah China pada tahun 1955, sebagai wilayah tempat tinggal suku Wa. Ximeng berada di bagian selatan pegunungan Nushan ( $\mathrm{Nu}$ Shan 怒山), merupakan salah satu daerah di China yang berada di antara beberapa pegunungan yaitu Pegunungan Ximeng (Ximeng Shanmai 西盟山脉), Lasilong (Lasilong Shanmai 拉斯龙山脉), dan Panlong (Panlong Shanmai 盘龙山脉).

Suku Wa di provinsi Yunnan terbagi dalam tiga wilayah, yang pertama di bagian barat Sungai Lancang (澜沧) di antara daerah perbatasan China dan Burma. Yang ke dua di pusat kabupaten Ximeng, biasa disebut daerah A Wa Shan (阿㑑山), termasuk daerah Lancang, Menglian (孟连) dan sebagainya. Yang ke tiga Ximeng bagian selatan 
termasuk daerah Menghai Jinghong (盟海景鸿) dan daerah Meng La (猛拉). Disebelah timur laut kabupaten Ximeng berbatasan dengan kabupaten Lancang, sebelah selatan berbatasan dengan kabupaten Menglian dan sebelah barat laut berbatasan dengan Myanmar (Miandian 缅甸). Daerah ini merupakan daerah sub-tropis yang memiliki dua musim yaitu musim panas yang jatuh pada bulan Juni hingga Desember dengan suhu ratarata $21^{\circ} \mathrm{C}$ sampai $27^{\circ} \mathrm{C}$ dan musim dingin yang jatuh pada bulan Januari hingga Mei dengan suhu rata-rata $8^{\circ} \mathrm{C}$ sampai $17^{\circ} \mathrm{C}$. Luas daerah kabupaten Ximeng adalah $1,391 \mathrm{~km} 2$ dan $1,214 \mathrm{~m}$ diatas permukaan laut.

\section{Nenek Moyang Suku Wa}

Ahli antropologi mengatakan nenek moyang suku Wa sama dengan suku Han, terlihat dari budayanya yang berkembang pada abad ke-tujuh dimasa kejayaan dinasti Tang. Ada beberapa cerita rakyat dan legenda tentang suku Wa. Sejak dahulu kala, orang-orang suku Wa di wilayah Ximeng dan Cangyuan provinsi Yunnan tinggal di dalam gua. Konon dewa menciptakan bumi dan menempatkan orang-orang di dalam gua. Gua-gua itu terukir secara alami yaitu berasal dari burung mematuki dindingdinding gua sehingga membentuk ukiran yang indah.

Menurut catatan, suku Wa adalah keturunan suku Baipu (摆谱) yang hidup sebelum periode dinasti Qin (221 SM - 26 SM). Mereka disebut Wangman (王曼), Guci (骨刺) atau Kawa (卡瓦) pada zaman dinasti Tang, Ming dan Qing. Sebutan itu terus digunakan hingga pada tahun 1949 secara resmi namanya diganti menjadi Wa oleh pemerintah China. Di berbagai tempat di Propinsi Yunnan mereka menyebut dirinya dengan sebutan yang berbeda. Misalnya, yang tinggal di daerah Ximeng, Menglian dan Lancang menyebut diri mereka Ah Wa (阿瓦) yang berarti gunung karena sebagian besar dari mereka tinggal di gunung. Di daerah Cangyuan, Shuangjiang dan Gengma disebut Ba Raoke（巴绕克） yang berarti bebatuan karena mereka tinggal dibukit yang berbatu, sedangkan di daerah Yongde dan Zhenkang disebut Wa yang berarti orang keturunan putri Wa.

Selain itu, ada legenda tentang seorang pemuda yang bernama Ya Wei Lanjia (呀蔚蓝嘉) yang tinggal di Chiang Mai. Ia sangat ingin menikahi seorang perempuan bernama Zhang Daiwei (张戴维) atau biasa disebut putri Wa yang berarti putri gunung Awa. Putri Wa tidak ingin menikah dengan Ya Wei Lanjia, maka ia melakukan berbagai cara untuk menolaknya. Akhirnya dari atas bukit, sang putri melemparkan tombak ke rumah Ya Wei Lanjia tetapi tanpa sengaja tombak tersebut mengenai tubuh Ya Wei Lanjia sehingga ia meninggal dunia. Kemudian putri Wa melarikan diri ke gunung A Wa Shan.

Legenda lain menceritakan bahwa suku Wa keluar dari Sigang Li (司崗里) (sigang berarti labu yang tumbuh di gunung) dan li berarti keluar. Dikatakan bahwa di utara Myanmar, tidak jauh dari daerah Ximeng dan daerah Cangyuan. Saat itu, Dewa Langit menciptakan dua orang manusia bernama Daguya (大鼓雅) dan Yeli (叶莉), yang merupakan nenek moyang pertama suku Wa. Pada saat itu Deguya mengoleskan air liurnya pada Yeli, yang menyebabkan Yeli mengandung dan kemudian melahirkan generasi pertama Wa, oleh karena itu, sebagian besar orang memanggil mereka Sigang Li.

\section{Kehidupan Suku Wa Di Ximeng \\ Bahasa}

Pada tahun 1998, Kementerian Pendidikan China menyatakan sekitar 400 juta orang atau 30 persen dari populasi penduduk China tidak dapat berbicara bahasa nasional China, yakni bahasa Han. Hampir semua daerah di China memiliki bahasa daerahnya sendiri, seperti dialek Kanton, Hokian, Xinan Guanhua (西南官话) dan lain lain. Ximeng yang termasuk ke dalam China bagian barat daya adalah daerah yang masyarakatnya menggunakan dialek Xinan Guanhua. Dorongan dari Kementerian Pendidikan dan Partai Komunis China dalam mempromosikan bahasa nasional yang diutamakan ke daerah-daerah suku minoritas telah memperoleh tanggapan yang positif, begitu pula dengan suku Wa yang saat ini sebagian dari mereka telah mampu menggunakan bahasa nasional untuk berkomunikasi.

Dialek Wa termasuk dalam rumpun Bahasa Wa Burma. Dialek Wa dituturkan oleh suku Wa di wilayah Beijing, Shandong, dan beberapa tempat di Yunnan, juga dituturkan di negara Myanmar, Thailand, Laos, Kamboja bagian selatan. Sebelum dibentuk menjadi Daerah Otonomi Ximeng oleh pemerintah China pada tahun 1957, Ximeng terbagi menjadi tiga provinsi yang memiliki tiga dialek Wa yang berbeda-beda, yaitu dialek Ba Raoke yang terdapat di provinsi Beijing, Shandong dan Sichuan; dialek Awa yang digunakan di provinsi Henan, Hunan, dan Yunnan; dan Ba yang saat ini adalah dialek yang banyak digunakan di Daerah Otonomi Ximeng. Yang membedakan dari dialek-dialek tersebut hanyalah intonasinya saja. Ketiga dialek 
tersebut memiliki kesamaan yaitu dalam kosa kata dan tata bahasa. Yang membedakan adalah vokal pada dialek Ba Raoke diucapkan dengan nada ringan, dialek Awa diucapkan dengan nada yang lebih kuat, sedangkan dialek Ba diucapkan dengan pengucapan yang cepat.

\section{Agama/Kepercayaan}

Suku Wa percaya pada kekuatan alam dan menganggap segala sesuatu memiliki energi yang positif, misalnya air, gunung, dan kayu. Mereka menyembah alam, percaya bahwa gunung, sungai, dan pohon-pohon memiliki kekuatan dan dianggap sebagai hal gaib. Selain itu, mereka menganggap dewa dan roh sebagai nenek moyang. Mereka juga menyembah Dewa Matahari Li (李), Dewa Bulan Lun (伦), Dewa Api Neng (竜), Dewa Kekayaan $\mathrm{Nu}$ (钕, dan Dewa Air Ah-yong (阿勇) yang memiliki tugas dan tanggung jawabnya sendiri. Jika sesuatu tidak disengaja terjadi pada seseorang, maka dia harus memberikan persembahan kepada dewa. Misalnya mereka yang mengalami kesulitan air pada musim panas akan memberi persembahan kepada Dewa Air dengan cara memberi sesaji ditempat tempat sumber air seperti sumur dan sungai.

Kegiatan keagamaan yang sering diadakan untuk memperoleh perlindungan dewa di adakan setiap tahun dengan melakukan persembahan, dimulai dengan mempersembahkan sesajian kepada dewa Air, serta berdoa agar cuaca tetap baik dan memperoleh hasil panen yang baik. Selain itu, suku Wa juga memberikan sesajian untuk melindungi keluarga dari bahaya dan penyakit. Diperkirakan bahwa mereka menghabiskan sepertiga dari pendapatan tahunan mereka untuk kegiatan keagamaan. Dalam beberapa tahun terakhir ini, di antara mereka sudah ada yang memeluk agama Buddha atau Kristen.

\section{Rumah Adat}

Pemukiman suku Wa di Kabupaten Ximeng dan Caoyuan terdiri dari beberapa desa, dan setiap desa terdiri dari puluhan rumah. Sebagian besar rumah di desa Wa dibangun di puncak atau lereng bukit, gaya rumah mereka bervariasi tergantung lokasi. Sebagian besar rumah dibangun dari bambu dan berlantai dua. Lantai atas untuk anggota keluarga, sementara lantai dasar digunakan sebagai kandang ternak.
Pembangunan rumah baru biasanya dikerjakan secara gotong royong. Pada saat ada suku Wa yang membangun rumah, orang-orang desa biasanya membantu dan ada juga yang menyumbangkan kayu ataupun jerami sebagai hadiah. Umumnya sebuah rumah dapat selesai dalam satu hari atau paling lama lima hari. Setelah rumah selesai dibangun, penduduk Wa akan diundang ke rumah baru untuk menghadiri syukuran. Pemuda pemudi biasanya merayakan syukuran ini dengan makan-makan, menari, bernyanyi, dan minum bir hingga pagi hari, sedangkan orang tua biasanya hanya mengikuti perayaan makan makan saja hingga pukul 11 malam.

\section{Pakaian Adat}

Suku Wa menyukai warna merah dan hitam, sehingga pakaian adat mereka biasanya berwarna hitam dengan hiasan merah. Laki-laki suku Wa mengenakan mantel pendek berwarna hitam tanpa kerah serta celana panjang hitam yang longgar. Mereka selalu memendekkan rambut dan menutup kepala mereka dengan turban hitam atau merah yang dibentuk seperti tanduk. Seperti kaum perempuan, sebagian kaum laki-laki suka memakai anting, gelang, dan kalung yang terbuat dari bambu atau perak. Saat pacaran, laki-laki biasanya membawa tas kecil yang terbuat dari kulit dan membawa pedang di pinggangnya. Agar terlihat lebih maskulin, mereka juga senang membuat tato di tubuhnya. Tato ini biasanya berbentuk tanduk. Sementara itu, kepala desa memiliki gaya berpakaian yang berbeda, ia biasanya menutup kepala dengan kain merah. Benda-benda seperti matahari, bulan, bintang, naga, dan kepala banteng disulam pada pakaian mereka yang memiliki makna sebagai benda yang dianggap melambangkan jiwa kepemimpinan.

Perempuan muda (gadis) mengenakan jaket pendek berwarna hitam yang panjangnya hingga bagian atas perut, dan rok dengan motif garis merah dan hitam. Mereka biasanya memakai anting-anting besar yang terbuat dari kerang, hiasan manik-manik yang berwarna-warni, kalung perak tebal, dengan pita merah di sekitar pinggang dan memakai gelang yang terbuat dari rotan pada lengan dan kaki. Perempuan yang berumur lebih dari 50 tahun lebih suka memakai tutup kepala yang besar berukuran lima inci untuk menaruh bunga, rumput atau bahkan uang untuk berbelanja ketika pergi ke pasar. 


\section{PEMBAHASAN}

\section{Wooden Drum Festival Di Ximeng Provinsi Yunnan}

\section{Asal Mula Festival Wooden Drum}

\section{Agama/Kepercayaan Suku Wa}

Festival Wooden Drum merupakan festival yang dirayakan suku Wa untuk memperingati atau memberi persembahan kepada nenek moyang. Dalam festival ini mereka membuat drum kayu, melakukan tarian persembahan serta menyiapkan korban dengan menyembelih sapi sebagai persembahan. Festival ini dirayakan pada minggu pertama bulan pertama kalender $\mathrm{Wa}$ (bulan November) dan berlangsung selama tujuh hari yang merupakan festival tahunan rutin dan merupakan salah satu festival terbesar dan terpenting. Mulanya festival ini adalah festival yang bersifat keagamaan, namun kemudian berkembang menjadi festival yang bersifat hiburan. Saat festival ini berlangsung, suku Wa yang bekerja baik di pemerintahan maupun swasta akan diliburkan oleh pemerintah China. Festival ini dilaksanakan di pusat kota Ximeng. Seluruh masyarakat menyaksikan rangkaian kegiatan Festival Wooden Drum.

Sekitar tahun $20 \mathrm{M}$, penduduk Ximeng berkembang dengan pesat, diperkirakan sudah berjumlah lebih dari 50 juta jiwa. Daerah-daerah subur di sepanjang aliran sungai menjadi tempat pemukiman yang memberikan cukup makanan, yaitu padi yang merupakan bahan pokok utama. Tanaman yang berasal dari Champa (Vietnam) yang berkembang pada abad 11 seperti gandum, ubi jalar yang dapat tumbuh pada tanah yang sempit, ikut mendorong pertumbuhan jumlah penduduk suku Wa di Ximeng. Pada sekitar tahun $35 \mathrm{M}$, jumlah penduduk diperkirakan ada 100 juta jiwa, jumlah tersebut menurun menjadi sekitar 65 juta pada tahun $45 \mathrm{M}$. Sejak saat itu, laju pertumbuhan penduduk tidak terlalu pesat karena mengalami beberapa hambatan yang disebabkan oleh bencana alam (banjir, penyakit), peperangan, dan kerusuhan sosial.

\section{Wooden Drum Festival}

Dalam Wooden Drum Festival terdapat berbagai macam rangkaian kegiatan yang ditunggu-tunggu oleh masyarakat Ximeng, di antaranya ada tiga kegiatan utama yaitu Membuat dan Menarik Drum Kayu (Lamugu 拉木鼓), Tarian Drum Kayu (Muguwu 木鼓舞), dan Sembahyang kepada Drum Kayu (Jimugu 祭木鼓), serta terdapat pula kegiatan hiburan seperti perlombaan olahraga, pertunjukan opera atau karnaval. Masyarakat seluruh penjuru Ximeng datang ke lapangan pusat kota Ximeng untuk menghadiri festival Wooden Drum, mereka mendirikan tenda di sekitar lapangan dan berkemah hingga perayaan festival Wooden Drum berakhir. Festival ini juga menjadi momen bagi masyarakat Ximeng khususnya suku Wa untuk berkumpul bersama keluarga, mereka menyanyi dan menari bersama sambil menikmati hidangan yang telah mereka sediakan serta menyaksikan pertunjukan festival.

Membuat dan Menarik Drum Kayu (Lamugu 拉木 鼓)

Drum Kayu merupakan artefak yang diturunkan oleh nenek moyang suku Wa. Kondisi geografis yang beriklim tropis, memiliki hutan yang lebat, serta banyaknya jenis pohon yang tumbuh, membuat masyarakat Wa dapat dengan leluasa memilih batang pohon untuk membuat drum kayu dengan kualitas yang paling bagus. Drum kayu juga merupakan alat musik utama untuk pemujaan. Drum terbuat dari batang pohon yang bagian tengahnya akan dibuat lubang untuk membentuk rongga beresonansi untuk menghasilkan suara yang indah. Drum kayu dibuat oleh laki-laki suku Wa yang dipimpin oleh kepala desa dan Moba. Moba berwenang untuk menentukan batang pohon yang akan dijadikan drum, sedangkan kepala desa memimpin acara serta proses pembuatan drum kayu. Setiap desa Wa memiliki setidaknya satu drum kayu. Drum kayu dibuat dari batang pohon yang dipotong dengan panjang $2 \mathrm{~m}$ dan berdiameter $47 \mathrm{~cm}$, kemudian drum kayu diukir dengan ukiran-ukiran khas suku Wa yang indah berupa ukiran orang-orang yang sedang bekerja yang melambangkan suku Wa yang pantang menyerah. Setelah drum selesai dibuat, biasanya ditempatkan di sebuah rumah drum kayu yang bawahnya dialasi dengan kayu berbentuk balok melengkung. Drum kayu biasanya diganti dengan yang baru setiap tahunnya.

\section{Tarian Drum Kayu (Muguwu 木鼓舞)}

Saat perayaan Wooden Drum banyak penduduk Wa yang turut serta menabuh drum kayu dengan bermacam-macam ukuran. Suku Wa di kabupaten Ximeng memiliki kelompok-kelompok seniman yang ahli membuat dan menabuh drum kayu. 


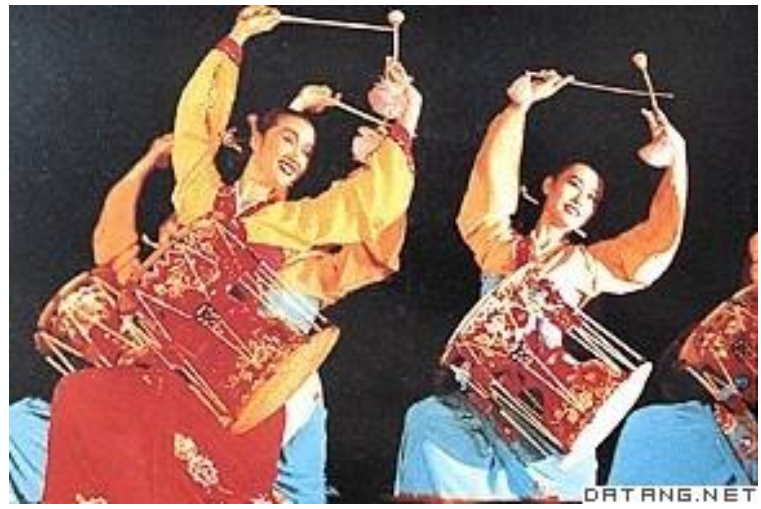

Sumber:

(http://www.dictall.com/indu/342/34131662E82.htm)

Dalam merayakan Festival Wooden Drum, digelar juga tarian khusus suku Wa yaitu Tarian Drum Kayu. Di desa Chen Bao (尘暴). Di Ximeng terdapat beberapa sanggar yang khusus mengajarkan tarian wooden drum. Sanggar ini didirikan oleh salah satu keluarga suku Wa di Ximeng, dan telah melahirkan 8 generasi seniman yang handal. Drum kayu suku Wa memiliki sejarah yang panjang dan dianggap sebagai simbol sejarah dan budaya dari suku Wa yang erat kaitannya dengan nyanyian dan tarian rakyat, sastra, seni serta agama. Tarian Drum Kayu dikategorikan sebagai tarian rakyat. Dalam perkembangannya, pada tanggal 20 Mei 2006 tarian Wooden Drum telah diakui sebagai salah satu warisan budaya non material di China. Antara lain menceritakan bahwa nenek moyang suku Wa diserang oleh suku lain yang mengakibatkan sebagian besar suku Wa bercerai berai. Dalam serangan itu, dua orang berhasil melarikan diri, yakni putri Yan Ni (闯妮) dan putranya Yegu （液 固 ). Kemudian mereka tinggal di pegunungan selama berbulan-bulan, setiap harinya mereka hanya ditemani oleh suara burung dan jangkrik. Suatu hari, mereka mendengar burung pelatuk yang mengeluarkan suara begitu indah. Lalu Yegu mendekati burung itu dan menemukan bahwa pohon yang dihinggapi burung itu telah berongga. Kemudian kayu itu ia tebang dan dijadikannya drum. Pada suatu hari, Yegu berinisiatif untuk menyatukan kembali sukunya yang telah terpisah, ia pun mendatangi desa-desa dimana suku Wa berada dan mengadakan perlombaan adu yak. Yak adalah sejenis kerbau yang banyak ditemukan di Pegunungan. Yak mudah dikenali dengan melihat bulu-bulunya (atau lebih tepatnya rambut) yang tebal \& panjang. Karena suku Wa terkenal dengan keahliannya mengadu yak, maka Yegu mengadakan perlombaan ini. Setelah berhasil menemukan beberapa suku Wa, Yegu mempertunjukkan gerakan tarian yang ia pelajari, kemudian selama tinggal di pegunungan sambil menabuh drum kayu yang kemudian diajarkannya kepada seluruh suku Wa yang telah dikumpulkannya. Mulai saat itu terciptalah Tarian Drum Kayu.

Sembahyang kepada Drum Kayu

Acara sembahyang kepada drum kayu dilakukan dengan menyembelih sapi sebagai kurban, pada saat itu para pria dan wanita mengenakan kostum terbaik mereka. Para ibu menyiapkan hidangan berupa daging babi, anggur, serta nasi ketan. Acara ini merupakan rangkaian terakhir dari Wooden Drum Festival. Orang-orang Wa baik pria, wanita, tua, maupun muda mengenakan baju baru. Mereka menari sambil bergandengan tangan dan mengitari drum kayu. Seluruh lagu dan tarian pada acara ini memiliki makna ungkapan kegembiraan atas selesainya pembuatan drum kayu. Suara drum yang menggelegar, nyanyian yang indah, sorak sorai peserta, serta tarian yang penuh semangat menunjukkan perasaan bahagia dan semangat dari orang-orang Wa.

Tarian Drum Kayu masih tetap terjaga hingga saat ini dengan variasi baru dalam gerakan berbeda dan juga dipertunjukkan sebagai hiburan. Tarian yang penuh gairah dan antusias menjadi ciri khas dari tarian ini, juga merupakan salah satu warisan budaya suku Wa yang banyak diminati masyarakat. Saat ini, tarian ini banyak digemari tidak hanya di China bahkan hingga ke mancanegara seperti Myanmar, Vietnam, Inggris, Amerika Serikat, Kanada, Italia dan negara-negara lain.

\section{Fungsi Drum Kayu Bagi Suku Wa}

Suku Wa mengganggap drum kayu sebagai benda suci. Di setiap desa Wa dibangun sebuah rumah, khusus untuk menyimpan drum kayu. Mereka percaya bahwa drum kayu dapat berfungsi sebagai sarana komunikasi antara suku Wa dengan nenek moyang mereka, juga dipercaya dapat mengusir kejahatan dan mendatangkan perdamaian. Sebelum tahun 1958, kepala desa suku Wa menggunakan drum kayu sebagai alat untuk menakuti binatang buas, selain itu drum kayu juga berfungsi sebagai alarm. Apabila terjadi bencana di desa seperti kebakaran atau pencurian maka warga menabuh drum kayu untuk memanggil warga yang lain. Selain itu drum juga berfungsi sebagai alat musik yang digunakan sebagai hiburan.

\section{Kegiatan Pada Perayaan Wooden Drum Festival}

Setelah ketiga kegiatan utama Wooden Drum Festival selesai, dilanjutkan dengan kegiatan- 
kegiatan lain yang bersifat hiburan, kesenian maupun olahraga tradisional. Seperti pertunjukan opera, kompetisi olahraga, karnaval serta berbagai kegiatan lainnya. Kegiatan ini diikuti oleh seluruh suku Wa di Ximeng, bahkan akhir-akhir ini kegiatan ini dijadikan sebagai objek wisata turis lokal maupun mancanegara.

\section{Pertunjukan Opera Qing}

Suku Wa yang tinggal di sebelah barat Yunnan, China masih mempertahankan kesenian dan adat istiadatnya hingga saat ini. Banyak di antara mereka merupakan seniman lokal yang telah menarik perhatian industri kesenian nasional China. Salah satu kesenian yang masih ada hingga saat ini adalah opera Qing. Opera Qing telah banyak meraih penghargaan nasional serta telah melakukan beberapa kali pertunjukan di berbagai acara dan kota di China. Opera ini pada mulanya menggunakan dialek Wa, beberapa kegiatan menggunakan bahasa Mandarin dalam pertunjukannya karena tidak semua orang memahami dialek Wa. Seniman-seniman opera Qing ini berasal dari tiga desa di Ximeng yaitu Desa Tebu (特步), Wangjiazhai (王家寨), dan Manzai (满载). Sebelum dan sesudah Festival Musim Semi, rombongan seniman berkumpul untuk melakukan pertunjukan di berbagai acara Televisi maupun acara panggung terbuka. Opera biasanya dimainkan menggunakan boneka naga dan singa seperti halnya barongsai. Pada saat perayaan Wooden Drum, opera ini selalu dijadikan sebagai pertunjukan penutup sebagai tanda berakhirnya Wooden Drum Festival. Selama pertunjukan, seluruh warga yang menonton pertunjukan biasanya duduk melingkar di lapangan sambil menyalakan api unggun.

Pada masa Dinasti Qing, pertunjukkan opera kelompok suku Wa sudah menarik perhatian masyarakat. Hal ini juga merupakan kontribusi penting yang dilakukan oleh suku Wa untuk menjaga dan mengembangkan warisan opera suku Wa. Seniman-seniman berinisiatif untuk mengaransemen opera Qing dengan menambahkan iringan perkusi. Opera ini memiliki karakteristik budaya suku yang kuat. Pemain opera biasanya lakilaki yang terdiri dari 12 orang pemain dan enam orang berada di belakang layar untuk menyiapkan kebutuhan saat pertunjukan. Alat musik yang biasanya mengiringi opera ini adalah erhu dan drum kayu, dan biasanya opera berakhir pada tengah malam.
Piao Niu 剽牛

Perayaan ini merupakan kegiatan pada perayaan Wooden Drum Festival yang paling ditunggutunggu. Konon katanya pada zaman dahulu, suku Wa melakukan persembahan kepala manusia kepada Dewa, tetapi kemudian digantikan dengan kepala kerbau yang merupakan simbol kekayaan. Suku Wa yang tinggal di Ximeng bagian barat percaya akan cerita ini. Hal ini dianggap sebagai pengabdian kepada Dewa dengan mempersembahkan kepala kerbau sebagai bentuk rasa syukur mereka terhadap ternak yang mereka pelihara karena beternak merupakan mata pencaharian utamanya.

Pada zaman dahulu, di Ximeng ada sebuah legenda yang menceritakan bahwa pada suatu hari banyak kerbau yang terkena wabah sehingga banyak yang mati. Orang-orang ketakutan dan meminta nenek moyang mereka untuk membantunya. Konon katanya awal mula munculnya wabah itu adalah karena pada waktu suku Wa berada dalam kemakmuran, mereka lupa untuk memberi persembahan kepada para dewa sehingga akhirnya dewa marah lalu menurunkan wabah tersebut. Nenek moyang suku Wa mulai menyadarinya kemudian membuat persembahan berupa kepala kerbau. Persembahan dilakukan dengan cara meletakkan kepala kerbau yang sudah dipotong di atas pohon sambil diiringi tabuhan drum kayu. Setelah melakukan persembahan selama beberapa malam, akhirnya wabah pun mulai surut.

Pada saat perayaan, suku Wa mempersembahkan seekor kerbau. Semua lapisan masyarakat hadir berpartisipasi dalam upacara tersebut. Malam sebelum acara, para ibu menyiapkan makanan dan Moba membuka acara. Setelah itu mereka bernyanyi dan menari di tengah lapangan dengan harapan selalu diberikan kebahagiaan agar ternak mereka dapat berkembang biak.

\section{Pacu Banteng}

Setiap perayaan Wooden Drum Festival terdapat beberapa acara hiburan yang digelar salah satunya adalah perlombaan pacu banteng yang merupakan olahraga tradisional suku Wa. Pacuan banteng pada umumnya hampir sama dengan pacuan kuda. Para penunggang banteng harus berpacu secepat mungkin berlomba menuju garis akhir melawan peserta lainnya. Penunggang yang sampai pertama kali di garis akhir adalah pemenang dari perlombaan tersebut. Perlombaan ini dilakukan di lapangan pusat kota Ximeng atau padang rumput yang luas tanpa lintasan, berjarak $2 \mathrm{~km}$, dan pesertanya biasanya terdiri dari 10 hingga 12 penunggang banteng. 
Banteng adalah binatang yang hidup di dataran tinggi dan mampu berjalan di lereng gunung serta tebing gunung yang curam. Banteng merupakan sarana transportasi bagi suku Wa untuk mengangkut barang-barang, namun banteng bukanlah hewan pelari seperti kuda, hal inilah yang menjadi tingkat kesulitan bagi para peserta. Selain bersaing untuk menjadi yang pertama kali sampai di garis akhir, para penunggang juga harus mampu mengendalikan banteng mereka selama perlombaan. Membutuhkan waktu yang lama untuk menjinakkan seekor banteng agar dapat mengikuti perlombaan banteng-banteng yang sudah terlatih dan terbiasa mengikuti perlombaan tetap harus dilatih secara rutin.

Pada saat perlombaan dimulai tidak semua banteng patuh mengikuti perintah tuannya, beberapa diantaranya bisa menjadi sangat agresif dan menyerang banteng peserta lain. Ada juga banteng yang terkejut ketika mendengar riuh penonton lalu menyerang mereka, dan ada yang hanya diam saja tidak bergerak ketika perlombaan sudah dimulai. Hal-hal tersebut mengundang tawa dan kemeriahan dari para penonton serta semakin mewarnai perlombaan menjadi lebih menarik dan menyenangkan untuk disaksikan. Tidak ada syarat dan ketentuan khusus maupun batasan umur bagi para peserta maupun banteng untuk dapat mengikuti perlombaan ini, namun biasanya para pesertanya adalah orang dewasa yang bermata pencaharian sebagai petani atau peternak, penggembala banteng atau pemelihara banteng. Banteng yang menjadi peserta perlombaan umumnya adalah yang jantan, karena yang jantan dianggap lebih kuat dan tangguh dibandingkan dengan yang betina.

Sebelum perlombaan para peserta memasang pelana dan cincin hidung pada banteng mereka, kemudian tali kendali diikat pada cincin hidung banteng yang berguna untuk mengendalikan arah banteng berjalan. Para peserta juga mendandani banteng mereka dengan hiasan berwarna-warni dan berbentuk rumbai serta pita yang terbuat dari kain sutera di kepala, tanduk, telinga, dan ekor. Hiasan-hiasan tersebut adalah sebagai simbol keberuntungan dengan harapan mereka untuk memenangkan perlombaan itu. Para peserta mengenakan pakaian tradisional suku Wa dan biasanya membawa cambuk untuk melecut banteng saat perlombaan agar dapat berlari lebih kencang. Banteng yang berhasil menang akan mendapatkan perlakuan istimewa dari tuannya serta memiliki harga jual yang tinggi. Sedangkan penunggangnya akan mendapatkan hadiah berupa sejumlah uang serta tepukan meriah dari para penonton.

\section{Perlombaan Perahu Naga}

Perahu naga mempunyai sejarah lebih dari 2000 tahun dan merupakan legenda tentang $\mathrm{Qu}$ Yuan （屈原） perdana menteri dari negara Chu ( 楚 国 ). Pada zaman itu (403 SM - 221 SM) China terbagi atas tujuh negeri yaitu negeri Qi (齐国), Yan（燕国）,Han（汉国）, Zhao（赵国）, Wei ( 卫国), dan Qin (秦国). Qu Yuan adalah menteri yang mepunyai banyak keterampilan seperti menulis dan ahli strategi. Ia juga memberikan saran untuk memajukan negara $\mathrm{Chu}$ dengan cara bergabung dengan negara Qi untuk melawan negara Qin.

Hal ini membuat ia dikritik dan difitnah oleh keluarga kerajaan yang tidak menyukainya sehingga ia harus pergi jauh dari negara Chu. Ia merasa sedih dan khawatir akan masa depan negara $\mathrm{Chu}$, kemudian ia bunuh diri dengan melompat ke sungai Miluo ( 汨罗江 Miluo Jiang ) yang terletak di provinsi Hunan (湖南). Rakyat yang merasa sedih kemudian mencari jenazah sang menteri di sungai tersebut. Mereka lalu melemparkan nasi dan makanan lainnya ke dalam sungai agar ikan-ikan tidak memakan jasadnya. Mereka juga membungkus makanan tersebut menggunakan daun agar tidak dimakan oleh naga. Makanan ini sekarang dikenal dengan sebutan bacang. Masyarakat Chu tidak putus asa terus mencari jasad sang menteri, mereka mengadakan perlombaan untuk menemukan jasadnya. Mereka mendayung sampan dan pemenangnya membawa hasil panen dan hidup bahagia di desa.

Perlombaan perahu naga ini biasanya dikuti oleh beberapa kelompok, masing-masing kelompok bekerja sama mendayung perahu naga untuk mencapai garis akhir. Di bagian depan perahu berdiri 3-4 orang untuk meramaikan suasana dan memantau laju kapal. Para pendayuh ada yang berdiri dibelakang dan ada yang duduk di bagian tengah. Di bagian tengah berdiri satu orang untuk menabuh drum kayu agar tim lebih kompak dan bergairah mendayung sesuai irama. Legenda lainnya mengatakan bahwa perlombaan perahu naga berasal dari pemujaan naga. Orang-orang harus membuat makanan yang akan di persembahkan kepada dewa naga dan perlombaan ini mencerminkan penghormatan kepada naga. Sampai saat ini beberapa suku minoritas di China masih 
melaksanakan perlombaan ini, yaitu suku Dai dan suku Wa pada saat perayaan Wooden Drum Festival.

\section{Kegiatan Mengoles Lumpur Hitam（Monihei 摸你} 黑 )

Monihei merupakan salah satu kegiatan yang meramaikan Wooden Drum Festival. Kegiatan ini disebut kegiatan mengoles lumpur sesuai dengan kebiasaan suku Wa mengoleskan abu, darah sapi atau lumpur di wajah orang lain untuk menghindari hal-hal yang buruk dan mencari kedamaian. Para pemain biasanya menggunakan cat alami untuk saling mencoreng dan saling mendoakan. Kegiatan ini telah menarik banyak wisatawan baik dari dalam maupun luar negeri, serta menghasilkan total pendapatan 100 juta yuan China setiap tahunnya dari industri pariwisata.

Monihei berasal dari dialek Wa, yang berarti "setelah saya menyentuhmu kamu akan berubah warna menjadi hitam" akan tetapi disisi lain Monihei memiliki makna inilah yang telah kita kejar dan harapkan, dan kita akan bertahan selamanya. Saat ini orang-orang suku Wa menggunakan tanaman alami yang disebut Niang Bu Luo (娘部落) untuk mewarnai tubuhnya. Menurut suku Wa, mengolesi Niang $B u$ Luo ke wajah atau tubuh seseorang dipercaya akan membawa berkah bagi suku mereka. Pada zaman dahulu, Niang Bu Luo terbuat dari abu, darah sapi dan lumpur. Saat ini banyak yang terbuat dari lumpur yang dicampur dengan wewangian sehingga menghasilkan aroma harum yang terbuat dari tanaman alami serta memiliki khasiat mencegah kulit yang hitam karena sinar matahari. Adapula beberapa Niang Bu Luo yang berbahan dasar coklat yang dapat membuat wajah menjadi harum dan halus. Pada saat perayaan, biasanya suku Wa mengenakan pakaian hitam bahkan beberapa wanita dari suku Wa mewarnai giginya dengan warna hitam menggunakan Niang Bu Luo khusus untuk mewarnai gigi. Selama kegiatan, orang yang tubuhnya paling penuh dengan lumpur dianggap yang paling cantik atau tampan. Mereka memilih warna hitam karena menurut suku Wa warna hitam mencerminkan keberanian serta melambangkan kerja keras.

\section{Alat Musik Pengiring Pada Perayaan Wooden Drum \\ Festival}

Selain diiringi dengan alat musik utama yaitu drum kayu, Wooden Drum Festival juga diiringi dengan alat musik lain dalam mengiringi segala kegiatan festival sejak hari pertama hingga berakhirnya perayaan. Alat musik yang mengiringi perayaan diantaranya adalah Duandi 短笛, Dangli 当策, Lixi 策西 dan Hulusi 葫芦丝. Fungsi alat musik pengiring ialah agar suasana menjadi lebih hidup. Misalnya saja pada saat Moba membaca mantera maka iringan musiknya juga harus menggambarkan alunan nada yang khidmad. Selain itu juga sebagai penambah semarak dan semangat bagi para penari.

Dalam bukunya yang berjudul Seni pertunjukan Indonesia di era globalisasi, Sudarsono mengatakan elemen dasar dari tari adalah gerak dan ritme, Maka elemen dasar dari musik adalah nada Ritme dan Melodi. Sejak zaman prasejarah sampai sekarang dapat dikatakan dimana ada tari disitu pasti ada musik, musik dalam tari bukan hanya sekedar pengiring, tetapi musik adalah patner tari yang tidak boleh ditinggalkan, musik dapat memberikan suatu irama yang selaras sehingga dapat membantu mengatur ritme atau hitungan dan dapat juga memberikan gambaran dalam ekspresi suatu gerak (1997 : 46).

Selain itu, irama musik juga dapat mengatur tempo tarian. Dalam hal ini jika alunan musiknya santai maka gerakannya juga harus santai. Fungsi musik pengiring yang terakhir pada perayaan Wooden Drum Festival adalah untuk memberikan tanda perubahan untuk perubahan suatu bentuk gerakan. Berikut adalah alat musik pengiring pada perayaan Wooden Drum Festival:

\section{Duandi (短笛)}

Duandi merupakan instrumen khas suku Wa yang berupa seruling, instrumen ini populer di kalangan suku Wa di daerah Ximeng. Duandi terbuat dari bambu, dengan panjang sekitar $16 \mathrm{~cm}$, serta memiliki lubang yang berjumlah 7 , dimainkan sama persis seperti saat kita meniup seruling. Suara yang dihasilkan oleh duandi bernada tinggi dan nyaring. Cara memainkannya dengan cara menutup lubang di bagian belakang dengan ibu jari tangan kiri. Setelah itu tutuplah lubang paling atas di bagian depan yang berada tepat di bawah tempat meniup dengan telunjuk tangan kiri. Gunakan ibu jari tangan kanan untuk menyeimbangkan posisi duandi. Jari pada tangan kanan akan bergerak dengan cepat membuka dan menutup lubang untuk menghasilkan suara yang indah.

Duandi biasanya terbuat dari bahan kayu, logam maupun plastik. Konon katanya Duandi yang terbuat dari kayu memiliki suara jauh lebih kuat dan nyaring daripada suara Duandi yang terbuat dari logam. Saat ini, banyak terdapat Duandi yang terbuat dari bahan 
sintetis plastik. Duandi yang terbuat dari bahan sintetis plastik terbukti lebih tahan lama dalam penggunaannya.

\section{Dangli (当策)}

Dangli merupakan alat musik dengan panjang $18 \mathrm{~cm}$, dan diameter $1,5 \mathrm{~cm}$. Terbuat dari bambu putih, hampir sama dengan duandi, akan tetapi suara yang dihasilkan lebih lembut daripada Duandi. Alat musik ini dimainkan dengan cara ditiup sama halnya dengan alat musik seruling. Biasanya dimainkan oleh laki-laki suku Wa. Suku Wa percaya bahwa saat mereka sedang memetik alat musik Dangli, maka Dewa akan turun untuk memberikan perlindungan kepada seluruh umat manusia. Dengan kata lain, pada zaman dahulu Dangdi juga dianggap sebagai alat musik untuk memanggil Dewa.

Saat kegiatan Piao Niu pada Wooden Drum Festival juga biasanya diiringi dengan petikan Dangli dengan tujuan mengantarkan kerbau yang dijadikan sebagai kurban ke surga. Sejak tahun 1970, Dangli mulai diresmikan sebagai alat musik tradisional suku Wa oleh pemerintah China. Saat ini, Dangli juga digunakan sebagai alat musik untuk menyatakan cinta pria kepada wanita juga sering digunakan untuk melamar pujaan hatinya.

\section{Lixi (策西)}

Instrumen ini merupakan salah satu instrumen favorit wanita Wa, karena ukurannya yang kecil dan ringan. Terbuat dari bambu, dengan panjang $45 \mathrm{~cm}$, dan diameter $1,90 \mathrm{~cm}$. Memiliki ujung yang berbentuk segitiga dan terdapat empat lubang diatasnya. Pada saat perayaan Wooden Drum Festival, dalam beberapa kesempatan pria akan meniup dangli dengan sangat indah untuk menarik perhatian wanita yang disukainya, lalu jika wanita itu juga tertarik dengan si pria, biasanya wanita akan meniup Lixi dengan cepat selama tiga kali, dan mereka akan meniupnya secara bersamaan.

Saat ini Lixi biasa dimainkan pada saat upacara pernikahan suku Wa, pengantin pria biasanya akan memainkan Lixi untuk pengantin wanita nya sebagai tanda ungkapan cintanya. Akan tetapi lambat laun Lixi beralih fungsi sebagai alat musik yang diaminkan oleh orang tua untuk menghilangkan rasa bosan.

\section{Hulusi (葫芦丝)}

Hulusi juga merupakan alat musik yang terkenal di kalangan suku Wa dan suku Dai di Yunnan China.
Hulusi (pluit labu) adalah instrumen yang ideal untuk mengekspresikan perasaan yang lembut dan mempunyai tinggi nada satu oktaf. Beberapa suku minoritas lainnya seperti suku Dai dan suku Yi di daerah perbatasan Yunnan juga menggunakan hulusi sebagai alat komunikasi. Hulusi terbuat dari bambu kuning yang diberi lubang-lubang kecil untuk menentukan suara dan nada jika ditiup. Bentuk hulusi berbeda-beda sesuai dengan daerah tempat pembuatannya. Alat musik ini biasanya dimainkan bersama-sama untuk mengiringi tarian, festival dan upacara. Beberapa tahun terakhir para pembuat hulusi membuat perubahan dan mengembangkan pembuatannya, yaitu dengan menggunakan kayu sebagai bahan dasarnya untuk meningkatkan suara dan tinggi nada mencapai dua oktaf ketika ditiup.

Ada sebuah legenda yang berasal dari suku Wa mengenai hulusi yaitu tentang seorang gadis cantik yang terancam hanyut pada saat banjir dahsyat. Ia mempunyai kekasih yang tampan dan pemberani. Kekasihnya bergegas menyelamatkan gadis tersebut dengan membawa seruling yang terbuat dari labu. Kesetiaan kekasih gadis tersebut menyentuh sang Budha dan merubah seruling labu yang di bawanya menjadi seruling emas, kemudian ia memainkan musik yang indah dengan seruling tersebut. Tidak lama kemudian banjir pun surut, bunga-bunga bermekaran dan burung-burung merak membentangkan ekor mereka yang indah. Legenda tersebut membuktikan bahwa kekuatan cinta dapat mengalahkan segalanya. Sejak saat itu seruling labu terkenal di kalangan suku Wa dan mereka mulai belajar untuk membuat seruling dari labu.

\section{Drum Bambu}

Drum bambu adalah instrumen perkusi suku Wa yang dikembangkan pada akhir tahun 1970an. Drum bambu ini memiliki panjang $100 \mathrm{~cm}$ dan berdiameter $35 \mathrm{~cm}$. Drum ini merupakan instrumen drum dalam keluarga instrumen musik perkusi dengan diameter berukuran besar untuk menghasilkan suara dalam intonasi nada rendah (bass). Bagian atas drum bambu biasanya dilapisi dengan kulit domba atau kulit kerbau. Instrumen ini pada dasarnya merupakan alat musik yang dapat menghasilkan suara baik karena dipukul, dikocok, digosok, diadukan, atau dengan cara apapun yang dapat membuat getaran pada benda tersebut. Drum bambu juga sering dijadikan sebagai souvenir oleh suku Wa saat perayaan-perayaan festival. Salah satunya adalah festival Wooden Drum. 
Saat memainkan alat musik ini, pemain biasanya berdiri dan menggunakan kedua tangan untuk memegang simbal kayu untuk memukul bagian atas drum. Pemain juga dapat memegang drum bambu di sekitar pinggang dengan tangan kiri. Drum menghadap ke depan dan tangan kanan memagang stik untuk menabuhnya. Drum bambu memiliki suara beresonansi tinggi, dan sering digunakan untuk iringan tari rakyat. Alat musik ini biasanya digunakan pada saat hari hari bahagia seperti salah satu hiburan pada pesta pernikan dan sebagainya. Drum bambu juga biasanya digunakan untuk mengiringi tarian.

\section{KESIMPULAN}

Suku Wa merupakan salah satu suku minoritas di China yang menganggap drum kayu sebagai benda suci. Untuk membuat drum kayu dan persembahan untuk nenek moyang mereka, suku Wa merayakan festival yang bernama Wooden Drum Festival yang juga merupakan festival keagamaan bagi suku Wa. Hingga saat ini festival ini masih terus dirayakan oleh suku Wa, karena mereka adalah suku yang sangat mematuhi ajaran agama.

Setiap minggu pertama bulan pertama kalender Wa (bulan November) selama tujuh hari berturut-turut suku Wa merayakan Wooden Drum Festival. Sebagian besar orang-orang di Ximeng memanfaatkan festival ini untuk berkumpul bersama keluarga dan kerabat. Dalam festival ini terdapat banyak kegiatan dan acara yang ditampilkan seperti pengorbanan kerbau dan pacuak banteng, namun kegiatan utama yang harus dilakukan adalah Pembuatan Drum Kayu Lamugu (拉木鼓), Tarian Drum Kayu Muguwu (木鼓舞) dan Pembuatan Kurban untuk Drum Kayu Jimugu (祭木鼓). Suku Wa menganggap drum kayu adalah benda yang dapat dijadikan sebagai alat komunikasi antara suku Wa dengan Dewa dan nenek moyang mereka, selain itu mereka juga percaya bahwa dengan menabuh drum kayu akan membawa berkah. Selain memancing dan membuat kerajinan tangan dari perak, mata pencaharian utama suku Wa adalah bertani. Oleh sebab itu mereka sangat menjaga kelestarian pohon-pohon yang terdapat di hutan Ximeng.

\section{REFERENSI}

[1] L. Yongxiang, "The Music of China's Ethnic Minorities”, Beijing: China Intercontinental press, 2006

[2] M. Sophie, "Menjelajah Dunia Mengenal China: 56 Potret Etnis China", Yogyakarta: Galangpress, 2011

[3] P. Meiutami, Skripsi, "Festival Xishuangbanna di Yunnan", Jakarta: Fakultas Ilmu Budaya Universitas Al Azhar Indonesia, 2

[4] L. Wang, "Keberuntungan Anda Pada Tahun Naga Air 2012”, Jakarta: Transmedia Pustaka, 2012

[5] 李玉, 西盟自治县, 云南民族网, 2003（Lǐyù, Xī méng zizhìxiàn. Yúnnán mínzú wăng, 2003)

[6] 王钟健,低族, 新疆新疆美术摄影出版 社 ,2012 (Wángzhōngjiàn,Wăzú, Xìnjiāng xīnjiāng měishù shèyìng chūbăn shè, 2012)

[7] 赵鹏, 了解中国㑑族木鼓节就去云南, 2015 (Vid) (Zhào péng.2015. Liǎojiě zhōngguó wăzú mù gǔ jié jiù qù yúnnán (Vid), 2015

[8] 赵富荣,中国低族文化, Beijing, 民族出版社, 2004 (Zhàofùróng, Zhōngguó wăzú wénhuà, Běijìng, Mínzú chūbăn shè, 2004)

[9] 韩, 军学仾族村寨与低族传统文化: 云南 西盟县大马散寨村寨建设调查, 四川大学,四 川: 2007 (Hán, jūn xué wăzú cūnzhài yǔ wăzú chuántǒng wénhuà: Yúnnán xī méng xiàn dà mă sàn zhài cūnzhài jiànshè diàochá, sìchuān dàxué, sìchuān:2007)

[10] 岩再,西盟佤族自治县概况,民族出版社, 北 京,2008 (Yán zài, xī méng wăzú zìzhìxiàn gàikuàng, mínzú chūbăn shè, běijīng, 2008)

[11] 张宗红, Studies in National Art of Yunnan, Yunnan University Press, 2015

[12] Alpizar dan Khotimah, Civil Religion (Fenomena Ajaran Tridharma di Riau). Pdf

[13] B. A. Hakim, " Pelayanan Pemerintah terhadap Umat Khonghucu di Kota Pangkalpinang Profinsi Bangka Belitung”, Jurnal Multikultural \& Multireligius, Vol. IX, No. 35, 2010

[14] Rusnaini, "Kehidupan Sosial Budaya Etnis Cina", Jurnal Penelitian Humaniora, Edisi Khusus, pp: 99 - 114, 2006

[15] P. Wibowo, "Tionghoa Dalam Keberagaman Indonesia : Sebuah Perspektif Historis Tentang Posisi Dan Identitas", Jakarta: Universitas Indonesia, 2012 
[16] http://en.yunnantourism.com/content.aspx?id= 047151712279 diakses pada tanggal 9 Oktober 2017

[17] http://en.yunnantourism.com/content.aspx?id= 047151712279 diakses pada tanggal 26 Juni 2018

[18] Gatra, Sandro. Presiden SBY Ganti Istilah "China" Menjadi "Tionghoa": Kompas.com edisi Rabu, 19 Maret 2014
[19] http://nasional.kompas.com/read/2014/03/ 19/1458446/Presiden.SBY.Ganti.Istilah.China. Menjadi.Tionghoa

[20] http://www.sohu.com/a/137472734_154718. diakses pada tanggal 15 Januari pukul 21.30 WIB

[21] https://kbbi.web.id/apologia. diakses pada tanggal 4 Mei 2018 